Іващенко В. Л.,

д-р філол. наук, професор,

Інститут журналістики

Київського університету імені Бориса Грінченка
Ivashchenko Viktoriia,

Doctor of Philological Sciences,

Professor, Institute of Journalism

of Borys Grinchenko Kyiv University

УДК 81’1.001.4

ТЕРМІН ПЛЕБСОЛОГІЯ В УКРАЇНСЬКІЙ МОВІ

\title{
THE TERM PLEBSOLOGY IN UKRAINIAN LANGUAGE
}

\begin{abstract}
Анотація. У статті розкрито зміст терміна «плебсологія», проаналізовано його застосування $і$ трактування в різних наукових галузях. Наведено похідні термінологічні уиворення. Запропоновано екскурс в історію.

Ключові слова: плебсологія, плебсологічний (плебсологічні проблеми, плебсологічна проблематика, плебсологічні прочеси, плебсологічна наукова система, плебсологічне прогнозування), плебсопрочес.
\end{abstract}

Abstract. The term «plebsology» is revealed in the article, its application and interpretation in various scientific fields are analyzed, also its derived words are given. Historical aspects of the term «plebsology» are considered.

Keywords: plebsology, plebsological (plebsological problems, plebsological processes, plebsologicals cientific paradigm, plebsological forecasting), plebsoprocess.

$\mathrm{T}$ ермін плебсологія сьогодні ввійшов до наукового обігу юристів та філософів, активно продукуючи словотвірні похідні плебсологічний (напр., плебсологічні проблеми, плебсологічна проблематика, плебсологічні процеси, плебсологічна наукова система, плебсологічне прогнозування тощо), плебсопроцес. Фахівці використовують його на позначення: «сукупність теоретичних положень як система поглядів у філософсько-правовій галузі знань про проблеми поведінки юрби та людських мас, пов'язаних із ними процесів, їхнього впливу на державотворення, а також адекватної та неадекватної діяльності відповідних органів державних інституцій»; «сутність особливої форми діяльності людини і людських мас»; «філософсько-правове вчення»; «сукупність положень, система поглядів на масові процеси буття - національних і соціальних груп... »; «окреме вчення, яке в особливій формі пізнає світ поведінки людських мас, зокрема й у складних ситуаціях; впорядковані погляди на найбільш загальні й конкретні його проблеми <..>, зокрема питання співвідношення - 1) простору, часу і поведіки людських мас, 2) простору, часу, поведінки мас і виникнення та розвитку державності, 3) мислення і буття, 4) духу і природи, а також соціального»; «вчення про окремі і загальні поняття суспільного буття, що стосуються поведінки людських мас та їх окремих груп, зокрема виключно правового характеру. До таких понять потрібно віднести, наприклад, право народу на опір, класифікація масових заворушень, плеб- сологічні стадії готування до суспільних (масових) заворушень тощо. Тому завдання плебсології <..>, по-перше, на філософсько-правовому рівні виявити i вивчити загальні питання: 1) будови й моделі поведінки людських мас у різнорідних плебсологічних ситуаціях; 2) законів функціонування і розвитку поведінки людських мас у різнорідних плебсологічних ситуаціях; по-друге, завдання плебсології мають конкретно-індивідуальний характер міжправового значення, зокрема досліджувати: 1) попереджувальні заходи суспільних (масових) заворушень; 2) особливості плебсологічного прогнозування; 3) особливості досудового слідства кримінальних справ про масові заворушення; 4) особливості тактики проведення окремих слідчих дій у процесі досудового слідства кримінальних справ про масові заворушення» тощо [1, с. 11, 24, 25, 29].

Проте в останньому визначенні цього терміна натрапляємо на логічні помилки, зокрема на використання у дефінієнсі (визначенні поняття «плебсологія», яке стосується референта «вчення про поведінку людських / народних масс <..> я як об'єкта визначення), похідного терміна плебсологічний, зокрема плебсологічні [стадії], у плебсологічних [ситуаціях], плебсологічне [прогнозування], що спричиняє когнітивний дисонанс у розкритті змісту дефінієндуму (самого поняття «Плебсологія»), тобто плутанину між референтом «вчення» (об'єктом позамовної дійсності, який номінує термін плебсологія) і дефінієндумом «Плебсологія» (поняттям, 
зміст якого розкривають), що спричиняє певну тавтологію.

У фаховій літературі натрапляємо також на випадки некоректної сполучуваності терміна плебсологія, зокрема плебсологічне вчення (тавтологія), плебсологічний філософсько-правовий (небажане поєднання конкретної назви на позначення одного 3 різновидів філософсько-правового вчення з назвою на позначення цього вчення) тощо [1].

Зазначене розуміння терміна-новотвора плебсологія, витвореного в українській мові продуктивним способом складання транслітерованого іншомовного слова (іменника плебс від лат. plebs) i транспонованого в [терміно]компонент / [терміно]елемент / суфікс / частину складних слів (за визначенням різних дослідників) іншомовного слова (-логія від лат. logos / гр. 入оүía) за допомогою з'єднувального голосного («0»), грунтується на семантиці лат. Plebs «плебс; народна маса; простий народ» [2, с. 471], «Тhe common people; the populace» / «простий народ; населення» (Dictionary of the English Language, Fourth Edition copyright (C) 2000 by Houghton Mifflin Company. Updated in 2009), «the common people; the masses» / «простий народ, маси» (Collins English Dictionary Complete and Unabridged (c) Harper Collins Publishers 1991, 1994, 1998, 2000, 2003), яке не має зневажливого забарвлення. Пор. з іншими значеннями: «натовп; рядовий склад», «чернь» [2, с. 471], «у Стародавньому Римі - частина народу, яка не була в рабстві, мала особисту свободу, але не могла користуватися політичними правами на рівні з патриціями», «у Західній Свропі в середньовічну добу та пізніше - широкі прошарки міської бідноти», «перен. простолюд; чернь; малоосвічені люди, схильні до розваг і не здатні до напруженого духовного життя» [3, с. 543].

Відсутність у терміна плебсологія зневажливого значення пояснюємо також його відсутністю у спільнокореневого терміна плебісцит, англ. plebiscite (від лат. Plebiscitum від plebei, plebs), який у перекладі з латини означає «наказ народу» і який також нині втратив зневажливе значення, пор.: «різновид народного голосування, за змістом близький до референдуму» [4, с.
371]. Цей факт засвідчують укладачі «Короткого Оксфордського політичного словника» за ред. І. Макліна й А. Макмілана (с. 505), які при цьому зазначають, що термін плебісцит, який відродив Вольтер для назви референдумів у Швейцарії, у XIX ст. уживали в Англії як зневажливий для характеристики референдумів, що їх організовували Наполеон I і Наполеон III, щоб зміцнити свою особисту владу (Там само).

Отже, вважаємо цілком правомірним використання в українській мові терміна плебсологія (за аналогією до терміна плебісцит) як нейтрального щодо стилістичного забарвлення або такого, що поєднує в собі і негативну, і позитивну раціональну оцінки, що, власне, й засвідчує визначення цього терміна в монографії M. I. Скригонюка «Плебсологія: правова сутність, теорія і практика» [1], де суспільні заворушення автор розглядає як з негативного (карного) погляду - масові заворушення, так і позитивного (життєдайного для суспільства поступу) - суспільні заворушення, спрямовані на захист прав і свобод людини.

\section{Список літератури}

1. Скригонюк М. І. Плебсологія: правова сутність, теорія і практика : монографія. - Київ : Видавн.-поліграф. центр “Київський ун-т”, 2005. - Ч. 2.

2. Трофимук М. Латинсько-український словник / М. Трофимук, О. Трофимук ; Львівська Богословська Академія. - Львів, 2001.

3. Сучасний словник іншомовних слів / I. О. Скопненко, Т. В. Цимбалюк. - Київ : Довіра, 2006.

4. Український дипломатичний словник / за ред. М. З. Мальського, Ю. М. Мороза. - Київ : Знання, 2011.

\section{Reference list}

1. Skopnenko, I. O. \& Tsymbaliuk, T. V (2006), Modern Foreign Dictionary, Dovira, Kyiv.

2. Skryhoniuk, M. I. (2005), Plebsology: Legal Essence, Theory and Practice: a Monograph, Vydavn.-polihraf. tsentr "Kyivskyi un-t", Kyiv, Part 2.

3. Trofymuk, M. \& Trofymuk, O. (2001), The LatinUkrainian Dictionary, Lviv Theological Academy, Lviv.

4. Malskyi, M. Z. \& Moroz, Yu. M. (Ed.) (2011), The Ukrainian Diplomatic Dictionary, Znannia, Kyiv.

Подано до редакиіï 12.02. 2017 p.

Иващенко В. Л., д-р филол. наук, проф.,

Институт журналистики

Киевского университета имени Бориса Гринченко

\title{
ТЕРМИН ПЛЕБСОЛОГИЯ В УКРАИНСКОМ ЯЗЫКЕ
}

\begin{abstract}
Аннотация. В статье речь раскрыто содержание термина «плебсология», проанализировано его использование и определение значения в разных научных сферах. Поданы терминологические производные. Предложено экскурс в историю возникновения и развития термина.
\end{abstract}

Ключевые слова: плебсология, плебсологический (плебсологические проблемы, плебсологическая проблематика, плебсологичекие прочессы, плебсологическая научная система, плебсологическое прогнозирование), плебсопрочесс.

Інтегровані комунікації, 201\% 